EUROPA REGIONUM TOM XXIII ROK 2015

DOI: $10.18276 /$ er.2015.23-16

\author{
IRENA ŁĄCKA \\ Zachodniopomorski Uniwersytet Technologiczny w Szczecinie
}

\title{
Ekoturystyka jako obszar działalności podmiotów ekonomii społecznej
}

\section{Wprowadzenie}

Eonomia społeczna staje się w ostatnich latach uznaną i upowszechnioną
metoda rozwiazywania tych społecznych problemów, którym ani państwo, ani rynek nie potrafią skutecznie zaradzić. Wśród nich znajdują się: bezrobocie, bezdomność, niepełnosprawność i wynikające z nich wykluczenie, wymuszające potrzebę integracji zawodowej i społecznej. Stanowi ona, jak wyjaśnia J. Hausner „określony segment działalności gospodarczej ulokowany w trójkącie, którego boki wyznaczaja - gospodarka rynkowa, społeczeństwo obywatelskie i państwo demokratyczne" (Hausner 2008, s. 11). W teorii i praktyce pozwala to dążyć do pogodzenia racjonalności alokacyjnej (utożsamianej z wolnym rynkiem), racjonalności dystrybucyjnej (przypisywanej państwu) oraz racjonalności solidarności (wynikającej z działania społeczeństwa) (Kwaśnicki 2005).

Sektor ekonomii społecznej jest komplementarny w relacji do rynku i państwa, stanowiąc ich uzupełnienie. Wynika to ze specyficznych wartości i cech, które charakteryzują ekonomię społeczną. Organizacje należące do tego segmentu gospodarki (m.in. spółdzielnie pracy i spółdzielnie socjalne, zakłady aktywności zawodowej, centra integracji społecznej, warsztaty terapii zajęciowej, towarzystwa ubezpieczeń wzajemnych, stowarzyszenia, fundacje) są zorientowane na społeczną użyteczność, a wypracowana przez nie nadwyżka służy realizacji celu społecznego.

Podmioty ekonomii społecznej funkcjonują na zasadach autonomii zarządzania, demokratycznego decydowania, pracy w lokalnym środowisku, z wykorzysty- 
waniem społecznego kapitału. Stawiają sobie za cel przeciwdziałanie wykluczeniu przez aktywne uczestnictwo w procesie reintegracji samych zainteresowanych. Podejmują działania w wielu obszarach, wypełniając przestrzeń lokalną w sferze usług społecznych oraz dóbr rynkowych, umożliwiając zatrudnienie grupom szczególnie zagrożonym na rynku (np. niepełnosprawnym, uzależnionym, długotrwale bezrobotnym, wykluczonym z powodu choroby lub konfliktów z prawem).

Wśród obszarów, w których podmioty ekonomii społecznej są obecne, znajduje się ekoturystyka. Jest to forma turystyki zrównoważonej, która aktywnie przyczynia się do ochrony dziedzictwa przyrodniczego i kulturowego, angażuje lokalne społeczności w planowanie i rozwój, zmierzając do poprawy ich dobrobytu. Tym samym staje się naturalną przestrzenią, w której mogą zaistnieć i znaleźć dla siebie szanse rozwoju podmioty ekonomii społecznej.

Celem tego artykułu jest omówienie, jak polskie podmioty ekonomii społecznej wykorzystują ekoturystykę do realizacji swoich zadań. Ze względu na ograniczone ramy tego artykułu omówiono tylko jeden przykład. Dodatkowo opracowanie ma wykazać, że działalność ta pozwoliła na osiagnięcie sukcesu gospodarczego przedsiębiorstwu społecznemu oraz wpłynęła na rozwój lokalnej społeczności.

Podczas przygotowywania artykułu wykorzystano dostępne źródła literatury krajowej i zagranicznej, materiały z portalu poświęconego ekonomii społecznej oraz informacje udosteppnione przez omawiane podmioty. Wśród metod zastosowanych podczas badania problemu znalazły się: analiza literatury oraz studium przypadku.

\section{Oddziaływanie ekonomii społecznej na społeczności lokalne}

Ekonomia społeczna (zwana także gospodarką społeczną lub trzecim sektorem) jest postrzegana jako katalizator oddolnego rozwoju społeczności lokalnej, wykorzystującego jej potencjał gospodarczy, społeczny, kulturowy, polityczny, ekologiczny i przestrzenny. Wpływ trzeciego sektora na społeczności lokalne wynika z pełnionych przez ten segment gospodarki funkcji. Wśród nich wymienia się cztery najważniejsze (Bohdziewicz-Lulewicz, Sutuła 2012):

- funkcję motora napędowego rynku pracy - koncentrowanie się na tworzeniu miejsc pracy dla osób zagrożonych wykluczeniem społecznym, świadczeniu usług doradztwa zawodowego, szkoleń zawodowych, staży itp., ułatwianiu wejścia na tzw. pierwszy rynek pracy;

- funkcję dostarczyciela usług socjalnych dla jednostek, zbiorowości i wspólnot lokalnych, zwłaszcza tam, gdzie zarówno państwo, jak i rynek okazują się 
niewydolne; w tym zakresie zadań mieści się dostarczanie usług deficytowych z punktu widzenia danej społeczności lokalnej, zwłaszcza usług pomocy społecznej, takich jak: usługi opiekuńcze, dożywianie, edukacja;

- funkcję twórcy kapitału społecznego - aktywność w tym segmencie gospodarki wywołuje mobilizację i pomnażanie kapitału społecznego, przypisywanego do jednostki (zwiększającego jej konkurencyjność w momencie uczestniczenia w sieci społecznej) oraz do grup lub całych społeczności (umożliwiającego wzajemne kontakty, wymianę informacji, budowę zaufania, wzajemności i wzmacniającego wzajemne relacje międzyludzkie, które są niezbędne do działania na rzecz wspólnego dobra);

- funkcję szkoły demokratyzacji - zaangażowanie członków społeczności lokalnych do przedsięwzięć na jej rzecz, ich udział w demokratycznym podejmowaniu decyzji, kształtowaniu celów i sposobów ich realizacji oraz wykonywaniu zadań, wynikających z podjętych decyzji; powoduje, że jednostki i grupy nabywają umiejętności i kompetencje niezbędne do funkcjonowania w świecie demokratycznym; postawy te, stając się pewnym nawykiem w obszarze podmiotów ekonomii społecznej, są przenoszone na inne dziedziny życia publicznego.

We współczesnym świecie oddziaływanie gospodarki społecznej sięga znacznie dalej i głębiej w strukturę społeczności lokalnych niż wskazują to cztery podstawowe funkcje. Ich realizacja sprzyja wywieraniu wpływu na zrównoważony rozwój lokalny. Jego podstawą stają się lokalne zasoby, potencjał miejsca i ludzi, oferujące lokalne przewagi konkurencyjne. Należą do nich:

- mieszkańcy danego terenu oraz ich umiejętności i kompetencje,

- potencjał przedsiębiorczości,

- zasoby kapitału rzeczowego i finansowego,

- szeroko rozumiane zasoby naturalne, w tym walory przyrodnicze i krajoznawcze,

- stan środowiska naturalnego,

- dziedzictwo kulturowe danego terytorium.

Wykorzystywanie tych specyficznych, charakterystycznych dla danego terytorium zasobów, wymaga zastosowania narzędzi marketingu terytorialnego i stworzenia przez podmioty ekonomii społecznej produktów i usług lokalnych, opatrzonych tzw. „,marką lokalną”. Odwołują się przy tym do tożsamości lokalnej, którą opisują wartości przyrodniczo-kulturowe oraz specyfika i cechy społeczności lokalnej. Podmioty gospodarcze (w tym z trzeciego sektora) podkre- 
ślają wyjątkowość swej oferty ze względu na wartości wyznawane przez lokalną społeczność. Wskazują na to, że podstawą ich produktów i usług są: tradycja, walory kulturowe, historyczne, przyrodnicze i krajobrazowe terytorium, a także przyjazność dla środowiska, tworzenie lokalnych miejsc pracy oraz promocja społeczności lokalnej (Brelik 2010; Raftowicz-Filipkiewicz 2013).

Obok oddziaływania na rozwój lokalny ekonomia społeczna sprzyja również pobudzaniu postaw przedsiębiorczych, rozwijaniu i mobilizacji kompetencji funkcjonowania na konkurencyjnym rynku pracy, ale w przypadku przedsiębiorstw ekonomii społecznej, których oferta trafia na rynek i rywalizuje z innymi, także zdolności do działania w warunkach konkurencji i prowadzenia podmiotów gospodarczych w sytuacji niepewności i występowania ryzyka ekonomicznego (Bohdziewicz-Lulewicz, Sutuła 2012).

\section{Pojęcie, cechy i rodzaje przedsiębiorstw społecznych}

Ze względu na wielostronne oddziaływanie ekonomii społecznej na społeczność lokalną i rozwój terytorialny jest ona od blisko dekady wspierana przez Komisję Europejską oraz krajowe władze publiczne i samorządowe, rozwijana przez organizacje pozarządowe, środowiska akademickie i eksperckie (Krajowy Program Rozwoju... 2014). W Polsce coraz intensywniej się rozwija i staje się stopniowo coraz bardziej złożonym segmentem krajowej gospodarki. Jej podmioty, mające bardzo różny charakter (fundacje, stowarzyszenia, zakłady aktywności zawodowej, centra aktywności zawodowej, warsztaty terapii zajęciowej, spółdzielnie pracy, spółdzielnie społeczne, spółki z o.o. organizacji pozarządowych, towarzystwa ubezpieczeń wzajemnych) mają wspólne cechy, choć różne zadania i pełnią wszystkie wymienione funkcje pomimo tego, że działają w bardzo różnych obszarach.

Spośród tych wszystkich podmiotów na szczególną uwagę zasługują przedsiębiorstwa społeczne, do których zaliczamy takie formy prawne, jak: spółdzielnie pracy, spółdzielnie społeczne, zakłady aktywności zawodowej, spółki z o.o. non-profit zakładane przez osoby fizyczne i prawne, takie jak np. fundacje i stowarzyszenia lub związki wyznaniowe.

Przedsiębiorstwa społeczne są w różny sposób definiowane. Tym terminem określa się działalność gospodarczą, „która wyznacza sobie cele ściśle społeczne i która inwestuje ponownie nadwyżki zależnie od tych celów w działalność lub we wspólnotę, zamiast kierować się potrzebą osiagania maksymalnego zysku na rzecz akcjonariuszy lub właścicieli” (Defourny 2005, s. 51). Dla J. Pearce „to ogólne 
określenie wszystkich podmiotów gospodarczych, które mają społeczny cel, nie są zorientowane na tworzenie i dystrybucję kapitału oraz mają demokratyczną, wymierną i opartą na wspólnym zarządzaniu strukturę" (Pearce 2003, s. 190).

Bardziej precyzyjnie istotę przedsiębiorstwa społecznego ujmuje T. Kaźmierczak podkreślając jego odmienność w stosunku do innych podmiotów trzeciego sektora. „Społeczne przedsiębiorstwa, w odróżnieniu od tradycyjnych organizacji non-profit, nie zajmują się rzecznictwem interesów jako głównym celem ani redystrybucją środków finansowych (jak np. fundacje przyznające granty), ale są bezpośrednio i trwale zaangażowane w produkcję dóbr i świadczenie usług dla różnych kategorii osób. Stanowi to podstawowy powód (albo jeden z głównych powodów) ich istnienia" (Kaźmierczak 2007, s. 110).

Pojęcie przedsiębiorstwa społecznego można również wyjaśniać podkreślając cele i zadania, które ono realizuje. Jak wskazują autorzy opracowania „Przedsiębiorstwa społeczne: czynniki trwałości. Raport z I fazy monitoringu przedsiębiorstw społecznych” stanowią one ,zespoły osób prowadzących niekomercyjną działalność gospodarczą mającą na celu reintegrację zawodową osób defaworyzowanych na rynku pracy lub przynoszenie korzyści społecznościom w postaci poprawy jakości życia ich członków, w tym także stymulowania lokalnego rozwoju społecznoekonomicznego, poprzez dostarczanie towarów i/lub usług użyteczności publicznej (Kaźmierczak, Przybysz, Potkańska 2011, s. 7-8).

Biorąc pod uwagę przedstawione definicje można wyodrębnić kilka najważniejszych cech przedsiębiorstwa społecznego. Jest ono dobrowolną inicjatywą grupy osób należących do danej społeczności lub dzielących te same potrzeby i cele. Osoby te zarządzają nim w ramach autonomicznego projektu, partycypacji i demokratycznych procedur, nawet w sytuacji zależności od publicznych subsydiów. Oznacza to, że przedsiębiorstwo społeczne charakteryzuje również wysoki poziom autonomii (Kaźmierczak 2007).

Jedną z istotnych cech takiego przedsiębiorstwa jest stawiany przed podmiotem gospodarczym cel społeczny - służenie społeczeństwu lub specyficznej grupie ludzi. Firma tego typu powstaje w celu oddziaływania społecznego i generowania zmian poprzez rozwiązywanie jakiegoś problemu społecznego lub zapobieganiu niesprawności rynku.

Poza tym przedsiębiorstwo społeczne cechuje podejście przedsiębiorcze, wykorzystujące narzędzia biznesowe, przedsiębiorczość, innowacyjność, metody rynkowe, orientację strategiczną, dyscyplinę i zdecydowanie, charakterystyczne dla przedsiębiorstw nastawionych na osiąganie zysku. Ze względu na łączenie wartości 
ekonomicznych i społecznych, dochody z działalności komercyjnej służą do finansowania celów społecznych. Dochody te nie podlegają restrykcjom, więc zapewniają swobodę finansową przedsiębiorstwu. W przedsiębiorstwie społecznym dokonuje się pomiaru wyniku finansowego oraz oddziaływania społecznego (Alter 2008). Jego działalność produkcyjna lub świadczenie usług wiążą się z ryzykiem gospodarczym i ekonomiczną weryfikacją efektów tej działalności. Osiagnięty zysk i skumulowany kapitał nie są przywłaszczane indywidualnie, lecz służą wypełnieniu określonej misji społecznej (Hausner, Laurisz 2008).

Wszystkie rodzaje przedsiębiorstw społecznych mają za zadanie realizować misję społeczną, która może występować w jednym z trzech typów, a to powoduje, że wyróżniamy trzy rodzaje takich przedsiębiorstw. Należą do nich przedsiębiorstwa: integracyjne, świadczące usługi użyteczności publicznej oraz zorientowane na rozwój lokalny. Mogą mieć również charakter mieszany, tzn. realizować więcej niż jedną misję.

Pierwsza kategoria wymienionych przedsiębiorstw realizuje społeczną misję, która polega na wprowadzaniu na rynek pracy i podnoszeniu poziomu umiejętności i kompetencji zawodowych, wytworzeniu odpowiednich postaw i nawyków osób wykluczonych (defaworyzowanych), ułatwiających im odnalezienie się na rynku pracy i zwiększających szanse na znalezienie zatrudnienia. Przedsiębiorstwa takie prowadzą działalność produkcyjną, usługową, ale także szkoleniową; część z nich jest aktywna na konkurencyjnych rynkach produktów i usług.

Natomiast przedsiębiorstwa świadczące usługi użyteczności publicznej starają się poprawić jakość życia członków lokalnych społeczności (lub pewnych kategorii społecznych). Wśród nich są takie, które świadczą usługi opiekuńcze, edukacyjne, zajmują się dożywianiem, oferują usługi noclegowe, wykonują usługi techniczne (np. utrzymywanie zieleni miejskiej i inne prace porządkowe związane z mieniem publicznym, niszczenie dokumentów, prace rozbiórkowe, usługi związane ze zbieraniem odpadów, ich segregacją i utylizacją, usługi o charakterze wzajemnym, jak np. ubezpieczenia wzajemne, usługi zdrowotno-opiekuńcze).

Trzecia grupa przedsiębiorstw społecznych jest ukierunkowana na wspieranie rozwoju lokalnego, a ich najważniejszym zadaniem jest aktywizacja ekonomiczna lokalnych społeczności. Najczęściej powstają jako stowarzyszenia lub fundacje, prowadzące dodatkowo działalność komercyjną, skupiające się na stworzeniu możliwości rozwoju ekonomicznego słabych, zaniedbanych, pozostających w stagnacji lub kryzysie społeczności lokalnych. Ich inicjatorem są liderzy lokalni, ale niekiedy inicjatywa tego rodzaju przychodzi z zewnątrz. 
Powstanie takiego przedsiębiorstwa społecznego wymaga wykorzystania zasobów danego terytorium (ludzkich, przyrodniczych, kulturowych, kapitałowych, politycznych itp.), które wcześniej nie były wykorzystywane w dostatecznym stopniu lub nigdy ich nie wykorzystywano, a nawet nie zdawano sobie sprawy $\mathrm{z}$ ich istnienia. W tej grupie przedsiębiorstw znajdują się te, które świadczą usługi turystyczne lub adresowane do turystów indywidualnych i grup zorganizowanych, prowadzą wioski tematyczne, ośrodki edukacji regionalnej lub ekologicznej, ekomuzea, skanseny, zajmują się również wytwarzaniem i sprzedażą lokalnych produktów rękodzielniczych, spożywczych lub gastronomicznych.

\section{Ekoturystyka jako rezultat zmian postaw i pragnień współczesnych turystów}

Wykorzystując Deklarację o Ekoturystyce (Québec Declaration on Ecotourism 2002) sformułowaną podczas międzynarodowej konferencji poświęconej ekoturystyce w Quebecu w 2002 r. można zdefiniować ekoturystykę (ecotourism) jako formę turystyki zrównoważonej ${ }^{1}$, skierowaną do turystów indywidualnych oraz podróżujących w małych grupach, która aktywnie przyczynia się do ochrony dziedzictwa przyrodniczego i kulturowego. Angażując lokalne społeczności w planowanie i wykorzystywanie zasobów lokalnych (przyrodniczych, kulturowych itp.) na potrzeby rozwoju danego terytorium i jego mieszkańców, umożliwia poprawę ich dobrobytu.

Według D. Zaręby ekoturystyka „to ekologicznie odpowiedzialne podróżowanie i zwiedzanie stosunkowo nietkniętych obszarów przyrodniczych, w celu czerpania zadowolenia i korzystania z bogactw natury (a także z wszelkich towarzyszących jej wartości kulturowych - zarówno przeszłych, jak i teraźniejszych), które promuje ochronę przyrody, ma niewielki negatywny wpływ na środowisko i stwarza możliwości aktywnego społeczno-ekonomicznego zaangażowania lokalnych społeczności" (Zaręba 2008, s. 7).

W XXI w. w wielu krajach coraz bardziej widoczne stają się zmiany mentalności, pragnień i postaw ludzi korzystających z oferty turystycznej. Przejawiają się one przede wszystkim w zwiększeniu ich świadomości ekologicznej, wymagań w zakre-

\footnotetext{
${ }^{1}$ Turystyka zrównoważona (sustainable tourism) to każda forma rozwoju turystycznego, zarządzania i aktywności turystycznej, która podtrzymuje ekologiczna, społeczną i ekonomiczną integralność terenów, a także zachowuje dla przyszłych pokoleń w niezmienionym stanie zasoby naturalne i kulturowe tych obszarów. Szerzej na ten temat: Zaręba (2006)
} 
sie jakości usług i oferty w postaci atrakcyjnego przyrodniczo i nieskażonego środowiska naturalnego w miejscu podróży i wypoczynku. Turyści, zwłaszcza z dużych aglomeracji miejskich, są coraz częściej zainteresowani spędzaniem wolnego czasu i rekreacją w otoczeniu ciszy, spokoju, wśród natury, z dala od zatłoczonych, modnych miejscowości wypoczynkowych. W tych miejscach pragną obcować z nieskażoną dziką przyrodą, przeżywać nieznane emocje, spożywać zdrowe posiłki, aktywnie spędzać wolny czas (jeżdżąc na rowerze lub konno, wędrując, obserwując lub fotografując zwierzęta, uczestnicząc w warsztatach twórczych itp.). Są zainteresowani poznawaniem nowych kultur lub krajów, albo odkrywaniem dotychczas niepoznanych aspektów dziedzictwa kulturowego własnego kraju.

Wyrażane przez część współczesnych turystów pragnienia, postawy i zasady postępowania wobec siebie i środowiska naturalnego wynikają z ich dążenia do uzyskania harmonii między własnymi potrzebami oraz potrzebami natury i lokalnych społeczności. Ekoturystyka jako element turystyki zrównoważonej skupia się na osiąganiu trzech celów - ekologicznego, ekonomicznego i społecznego, a to oznacza, że może stać się ona naturalnym obszarem aktywności podmiotów ekonomii społecznej.

Cel ekologiczny rozumiany jest jako zachowanie zasobów naturalnych wykorzystywanych na potrzeby turystyczne w jak najmniej naruszonym stanie oraz redukowanie zanieczyszczeń wynikających z użytkowania tych zasobów przez turystów. Drugi cel - ekonomiczny - wskazuje na zapewnienie dobrobytu ekonomicznego społeczności lokalnej w ramach działalności turystycznej oraz jak najlepsze utrzymanie i wykorzystanie istniejącej infrastruktury turystycznej. Obok tych celów powinien być również realizowany cel społeczny, odnoszący się do zapewnienia właściwego zaspokojenia potrzeb zarówno turystów, jak i mieszkańców danego terenu w ramach pełnienia przez niego funkcji turystycznych. Oznacza to z jednej strony przygotowanie właściwej oferty wypoczynku i rekreacji dla turystów w otoczeniu nieskażonego środowiska naturalnego, możliwości poznania jego dziedzictwa kulturowego, a jednocześnie generowania miejsc pracy dla lokalnej społeczności, ochronę jej kultury, dziedzictwa oraz możliwość wpływania przez ludność na kierunki rozwoju danego terytorium, w tym prowadzenia polityki turystycznej (Para 2013).

Europejską odpowiedzią na dążenie do osiągnięcia wspomnianych celów stał się od 2001 r. Program Zielone Szlaki - „Greenways”, który wspiera rozwój ekoturystyki, czyli turystyki przyjaznej dla środowiska. Idea ta promuje zdrowy i aktywny styl życia oraz wpływa na ożywienie lokalnej społeczności i jej rozwoju, przy jednoczesnym szacunku dla przyrody, kultury, krajobrazu i lokalnej toż- 
samości. W Polsce ten program również znalazł swoich pasjonatów, zarówno wśród władz samorządowych, organizacji turystycznych, podmiotów trzeciego sektora, jak i turystów. W naszym kraju Greenways obejmują już ponad 3000 km, a wsparciem tej inicjatywy zajmuje się Fundacja Partnerstwo dla Środowiska.

Zielone Szlaki stanowią szlaki dziedzictwa przyrodniczo-kulturowego. Tworzy się je wzdłuż tras kolei, rzek, tradycyjnych, historycznych tras handlowych, naturalnych szlaków przyrodniczych. Mają charakter szlaków rowerowych, pieszych, konnych, wodnych, a także innych - służących niezmotoryzowanym formom transportu i podróżowania. Ich organizacją i zarządzaniem zajmują się miejscowe społeczności, wykorzystując je w celu pobudzania zrównoważonego rozwoju. Greenways umożliwiają realizację lokalnych inicjatyw społecznych, projektów związanych z ochroną przyrody i krajobrazu, zachowaniem dziedzictwa kulturowego, tworzeniem podwalin ekoturystki i turystki zrównoważonej. Tego typy przedsięwzięcia często podejmowane są przez podmioty ekonomii społecznej.

„Zielone” szlaki turystyczne są przygotowane we współpracy lokalnych partnerów, tzn. organizacji pozarządowych (stowarzyszeń, fundacji, kół gospodyń wiejskich, związków gmin), klastrów, przedsiębiorstw społecznych, gospodarstw agroturystycznych, szkół oraz komercyjnych biur turystycznych. Oferta kierowana jest do turystów indywidualnych i grup zorganizowanych reprezentujących różne segmenty rynku. Obejmuje zajęcia w warsztatach twórców rękodzieła, poznawania tajników kulinarnych lokalnych przysmaków, zielone szkoły, aktywne i poznawcze oferty pobytowe w regionie, udział w rekonstrukcjach historycznych, wycieczki rowerowe, piesze, konne, kajakowe itp., możliwości spożycia lokalnych produktów, zakupu wytworzonych przez mieszkańców wyrobów kulinarnych i rękodzielniczych. Propozycje turystyczne zawsze wiążą się z wykorzystywaniem potencjału zasobowego lokalnej społeczności. Przygotowaniem i sprzedażą zarówno oferty turystycznej, kulturalnej, jak i rekreacyjnej lub gastronomicznej zajmują się mieszkańcy terenu, przez który przebiega ,zielony” szlak. Sprzyja to aktywizacji gospodarczej i zawodowej lokalnej społeczności, a także wpływa na jej rozwój i poprawę możliwości ekonomicznych danego terytorium (Zaręba 2008).

\section{Zielony Rower. Przedsiębiorstwo Społeczne jako przykład firmy działającej w ekoturystyce}

Jednym z przykładów aktywności podmiotów trzeciego sektora w obszarze ekoturystyki jest Fundacja Bieszczadzka Partnerstwo dla Środowiska z Leska 
i stworzone przez nią przedsiębiorstwo społeczne Zielony Rower. Koncepcja wykorzystania ekoturystyki dla rozwoju regionu i rozwiązania problemu młodych bezrobotnych osób $\mathrm{w}$ ramach przedsiębiorstwa społecznego zrodziła się w połowie pierwszej dekady XXI w. Od 2003 r. istniała w Lesku, stworzona z myślą o wspieraniu rozwoju lokalnego w regionie Bieszczad, Fundacja Bieszczadzka Partnerstwo dla Środowiska. Tereny te były dotknięte problemem wysokiego i długotrwałego bezrobocia (np. w powiecie leskim w 2004 r. stopa bezrobocia wyniosła $29,0 \%$, a 2009 r. $-24,6 \%$ ), a także bardzo wysokiego bezrobocia na terenach wiejskich (w 2004 r. w powiecie leskim aż 80,5\% ogółu bezrobotnych stanowiła ludność wsi), braku perspektyw dla osób młodych oraz odpływem części mieszkańców do innych regionów lub za granicę (Plan rozwoju lokalnego... 2004). Potencjał turystyczny tych pięknych terenów był wykorzystywany jedynie w niewielkim stopniu, a słabo rozwinięta oferta turystyczna okazywała się atrakcyjna dla pasjonatów wędrówek i życia wśród dziewiczej przyrody, ale akceptujących niski standard usług turystycznych. Korzystano z niej jedynie sezonowo i nie generowała istotnych wpływów $z$ turystyki. Nie zostawały one jednak w regionie, ponieważ inwestorami firm turystycznych (i z innych branż) byli w większości mieszkańcy z innych terenów. Ich podmioty gospodarcze najcześciej były zarejestrowane poza Bieszczadami, a to przyczyniało się także do niskich wpływów z podatków dochodowego i od osób prawnych (Prądnicki 2012).

Szansą na zmianę tego stanu rzeczy stało się zaangażowanie Fundacji Bieszczadzkiej w rozwój ekonomii społecznej na terenie Bieszczad. Posłużyło do tego wsparcie finansowe ze środków unijnych z programu Inicjatywy Wspólnotowej EQUAL „Gospodarka społeczna na Bursztynowym Szlaku”, którym administrowała Fundacja Partnerstwo dla Środowiska z Krakowa. Fundacja Bieszczadzka otrzymała dotację w 2006 r. w wysokości 900 tys. zł na stworzenie przedsiębiorstwa społecznego działającego w branży turystycznej i rozwijającego ekoturystykę w Bieszczadach. Nazwano je Karpackie Centrum Turystyki Aktywnej Zielony Rower Przedsiębiorstwo Społeczne. Nazwa ta nawiązywała do opisywanych w artykule szlaków Greenways jeden z nich przebiegał przez Karpaty Wschodnie i obejmował 1300 km na pograniczu Słowacji, Polski i Ukrainy (Zielony Rower Greenway Karpaty Wschodnie). Zgodnie z koncepcją takich szlaków nowo tworzone przedsiębiorstwo społeczne starało się podkreślać ekologiczny charakter swej działalności. Na rynku turystycznym istniały w tym czasie inne biura turystyczne i nowy podmiot musiał umieć znaleźć swoją indywidualną cechę. Stała się nim oferta turystyczna przyjazna dla środowiska, wykorzystująca bogactwo lokalnego dziedzictwa historycznego i kulturowego oraz 
wyjątkowość środowiska przyrodniczego i klimatycznego. Miała być ona kierowana do turystów indywidualnych i małych grup zorganizowanych, unikających zatłoczonych miejscowości wypoczynkowych, utartych szlaków, ale pragnących przeżywać przygodę oraz poznawać i doświadczać samej istoty danego terytorium (jego kultury, historii, dziedzictwa kulinarnego, religijnego itp.). Tego typu oferta turystyczna miała unikatowy charakter, ściśle wpisujący się w idee ekoturystyki.

Przedsiębiorstwo społeczne rozpoczęło swą działalność 1 czerwca 2006 r. posiadając koncesję touroperatora, a jego celem było organizowanie imprez turystycznych w całych Karpatach Wschodnich - nie tylko w Bieszczadach. Choć stanowiło biuro podróży, to jako podmiot ekonomii społecznej nie działało na podobnych zasadach, jak inne tego typu firmy. Wypracowany zysk przeznaczało na realizację celów społecznych, tzn. finansował działalność Fundacji Bieszczadzkiej, która przeznaczała je na fundusz grantowy dla organizowanych przez nią lokalnych projektów, realizowanych przez członków Grupy Partnerskiej „Zielone Bieszczady”. W pierwszym roku działalności zysk ten był niewielki - jedynie 15 tys. zł, jednak w 2010 r. okazał się dużo większy, ponieważ wyniósł 340 tys. zł (Szpak 2007; Cyło 2012).

Fundacja Bieszczadzka Partnerstwo dla Środowiska początkowo zdecydowała, że najprostszym rozwiązaniem dla organizowanego przedsiębiorstwa społecznego będzie uruchomienie go w formie wewnętrznej działalności gospodarczej tej organizacji. Nie wymagało to dużych nakładów finansowych, ani prowadzenia odrębnej księgowości i przygotowywania osobnego bilansu. Niestety po roku działalności Zielonego Roweru okazało się, że to rozwiązanie nie jest właściwe i efektywne. Firma nie miała osobowości prawnej, co wywoływało ograniczenia w jej funkcjonowaniu, ale stwarzało również zagrożenia dla Fundacji. Jak to wyglądało $\mathrm{w}$ praktyce prezentuje cytat $\mathrm{z}$ opracowania pod red. B. Kazior, A. Jarzębskiej i O. Gałek Firma społeczna w rozwoju lokalnym.

Autorzy tej publikacji stwierdzaja, że: „Trudno było np. wytłumaczyć kontrahentowi, dlaczego na fakturze pojawiają się dane Fundacji, skoro rozmowy o ofercie prowadził z firmą «Zielony Rower». Taka «podwójna osobowość» powodowała również komplikacje w kontaktach z urzędami i klientami. Nie było też możliwości pozyskania dodatkowego kapitału od wspólników, jak ma to miejsce w spółce. W przypadku negocjacji kredytowych z bankiem należało przedstawiać dokumenty finansowe całej Fundacji, z których kondycja firmy była trudna do odczytania. W momencie kryzysowym słaba kondycja przedsiębiorstwa społecznego stanowiła wręcz zagrożenie dla płynności finansowej Fundacji Bieszczadzkiej oraz dla jej 
relacji z partnerami lokalnymi w regionie. Dodatkowym problemem okazał się niejasny podział kompetencji i odpowiedzialności kadry organizacji i kierownictwa przedsiębiorstwa" (Kazior, Jarzębska, Gałek red. 2008, s. 33-34).

Opisane trudności i ograniczenia w rozwoju wpłynęły na konieczność zmiany formy prawnej firmy. Podjęto decyzję o zebraniu kapitału założycielskiego i stworzeniu spółki z o.o., której kierownik odpowiadał przed zarządem Fundacji. Zyski wypracowane przez spółkę miały być przekazywane na cele społeczne w ramach funduszu dotacyjnego (Funduszu Grantowego Grupy Partnerskiej „Zielone Bieszczady”2).

W funkcjonowanie przedsiębiorstwa społecznego zostało początkowo zaangażowanych 8 młodych, bezrobotnych osób, które długo nie mogły znaleźć pracy na lokalnym rynku. Ich zatrudnienie było dotowane w ramach projektu unijnego. W następnych latach część zatrudnionych osób podjęła decyzję o prowadzeniu samodzielnej działalności gospodarczej, współpracując dalej z „Zielonym Rowerem" i z Fundacją Bieszczadzką. Podstawą działalności tej firmy było organizowania i oferowanie ekologicznych form turystyki przyjazdowej w Bieszczady, a także proponowanie udziału w lokalnych warsztatach rękodzieła, możliwości zakupu produktów rękodzielniczych, charakterystycznych dla pogranicza Karpat Wschodnich.

Obok opisywanego przedsiębiorstwa społecznego z inspiracji Fundacji w lokalnym środowisku powstały inne przedsięwzięcia gospodarcze wykorzystujące dziedzictwo kulturowe regionu i możliwość współdziałania z touroperatorem (np. ekomuzea karpackie, restauracje). Jak wspomina jedna z właścicielek takiego „pomysłu biznesowego” pod nazwą „Rękoczyny. Pracownia Rękodzieła i Rzemiosła Artystycznego”, Magdalena Stanisławska z Chmielna, „współpraca z Zielonym Rowerem pozwoliła [...] w pewnym stopniu zwiększyć obroty [...]. Organizowane u mnie warsztaty rękodzielnicze są dodatkową promocją" (Cyło 2012, s. 15). Jej oferta w postaci wyrabianych koronkowych serwetek, temkowskich krywulek i batików oraz warsztatów ujawniających tajniki ich powstawania okazała się atrakcyjna dla turystów przyjeżdżających w Bieszczady, chcących aktywnie wypocząć w otoczeniu pięknej natury (jeżdżąc na rowerach, wędrując, podglądając ptaki itp.), a jednocześnie poznać kulturę i historię tych terenów.

${ }^{2}$ Szczegółowy opis autorskiego Modelu Bieszczadzkiej Gospodarki Społecznej, w których wpisuje się Zielony Rower został zaprezentowany w opracowaniu: Kazior B., Jarzębska A., Gałek O. (red.), Firma społeczna $w$ rozwoju lokalnym. Poradnik dla organizacji pozarzqdowych, Fundacja Partnerstwa dla Środowiska, Kraków 2008, s. 13-14. 
Powstanie Zielonego Roweru zainicjowało pozytywne zmiany w lokalnej społeczności. Pokazało, że proponowany sposób na rozwój regionu poprzez ekoturystykę przynosi sukcesy. Mieszkańcy uwierzyli w siebie i zaczęli dostrzegać w swoim otoczeniu niewykorzystany potencjał zasobów przyrodniczych, krajobrazowych, kulturowych i historycznych. Skłoniło to ich do współdziałania w ramach inicjatyw partnerskich i podejmowania indywidualnego ryzyka prowadzenia własnej działalności gospodarczej. W wyniku społecznego ożywienia i wiary w powodzenie pomysłu na ekoturystykę w następnych latach w Bieszczadach powstało kilka firm oraz kilkanaście stowarzyszeń. Niektóre z nich podjęły decyzje o stworzeniu spółdzielni socjalnych mających na celu działalność gospodarczą której zyski będą przeznaczane na cele społeczne. Przedsiębiorstwa te ukierunkowały się na działalność produkcyjną i usługowa, wytwarzanie lokalnych i regionalnych przysmaków kulinarnych i cukierniczych oraz ich dystrybucję, a także prowadzenie działalności restauracyjnej i kawiarnianej. Oferta tych i innych komercyjnych lokalnych firm wspomaga ofertę Zielonego Roweru i zapewnia właściwy i kompleksowy zestaw wartości uzyskiwanych przez ekoturystów w regionie Bieszczad.

Opisywane przedsiębiorstwo społeczne zmieniło swą nazwę 1 stycznia $2011 \mathrm{r}$. na Biuro Eko Podróży Zielony Rower. Zmodyfikowało też nieco działalność rozszerzając ją na tereny pogranicza w ramach Karpat Wschodnich, nadal jednak wykorzystując lokalne, bieszczadzkie zasoby (ludzkie, przyrodnicze, krajoznawcze i dziedzictwa kulturowego). Jego strategia biznesowa opiera się na trzech głównych elementach. Pierwszym z nich jest oferta jednodniowych wycieczek z przyrodnikiem, ornitologiem lub entomologiem pod nazwą „Dzikie Karpaty”. Kierowane są do miłośników świata ptaków, owadów lub rzadkich gatunków roślin zasiedlających bieszczadzkie lasy i połoniny. Ta propozycja może być wykorzystywana przez turystów w różnym wieku (indywidualnych, grup zorganizowanych), ale także szkoły, gdyż może być realizowana w postaci zielonych szkół.

Drugim elementem jest oferta jednodniowych wycieczek pokazujących wielonarodowy, wielokulturowy charakter terenów Bieszczad, ich historycznego i kulturowego dziedzictwa. Podczas tych wypraw turyści oprowadzani są przez historyków, znawców cerkwi i ikon. Proponuje się im również warsztaty rękodzielnicze. W ofercie są takie trasy, jak: Szlak Ikon, Szlak Dobrego Wojaka Szwejka, Szlak Nadsańskich Umocnień (Linia Mołotowa). W przypadku tej oferty Zielony Rower łączy siły z partnerami ze Słowacji i Stowarzyszeniem Pro Carpathia w celu szerokiego zaprezentowania wielokulturowości terenów Karpat. 
Ostatnim filarem oferty turystycznej są tzw. „Karpaty dla aktywnych”, czyli pakiet letnich usług turystycznych dla pasjonatów pieszych wycieczek, rajów rowerowych, propozycje dla żeglarzy i kajakarzy. Oferta zimowa zawiera natomiast pozycje rekreacji dla turystów, chcących skorzystać ze możliwości wypadów na nartach biegowych lub rakietach śnieżnych (Cyło 2012; Pyzocha 2014).

\section{Podsumowanie}

Ekoturystyka wiąże się z udostępnianiem turystom indywidualnym i małym grupom zorganizowanym unikatowej oferty turystycznej i rekreacyjnej w stosunkowo nietkniętych obszarach przyrodniczych z możliwością czerpania przyjemności i radości z korzystania z bogactw natury oraz towarzyszących jej innych walorów i wartości tych obszarów (kulturowych, etnograficznych i historycznych) bez wywierania negatywnego wpływu turystów na środowisko naturalne i otoczenie społeczne. Jej koncepcja stwarza ogromną szansę dla niektórych lokalnych społeczności, które dotychczas były w stagnacji lub rozwijały się bardzo wolno i nierównomiernie. W tradycyjnym modelu rozwoju lokalnego nie mają one odpowiednich warunków do wykorzystywania swych specyficznych zasobów (ciekawych niezniszczonych zasobów przyrodniczych, krajoznawczych, unikatowego dziedzictwa kulturowego, potencjału ludzkiego o bardzo różnorodnych, zanikających w nowocześniejszych społecznościach umiejętnościach, sprzyjającej określonym inicjatywom gospodarczym polityce lokalnej). Obszary, charakteryzujące się takim problemami rozwojowymi, cechuje wysoka stopa bezrobocia, rosnąca liczba niezamożnych, biernych i coraz starszych mieszkańców, wyludnianie się (młodsze pokolenie szuka pracy i miejsca do życia w innych regionach i poza krajem). Coraz trudniej jest w takich warunkach władzy lokalnej właściwie wypełniać jej zadania (np. w zakresie usług społecznych).

Przedstawiony przykład Bieszczad i działającej w nich Fundacji Bieszczadzkiej Partnerstwo dla Środowisko z Leska pokazuje, że możliwe jest znalezienie wyjścia $z$ takiej trudnej sytuacji poprzez połączenie ekonomii społecznej i jej podmiotów z ekoturystyką. Wymaga to na pewno silnego zaangażowania lokalnych liderów, którzy potrafią dostrzec potencjał specyficznych zasobów danego terytorium i znaleźć środki finansowe na rozwój (np. w ramach wspierania ekonomii społecznej), skupić wokół siebie osoby gotowe podjąć ryzyko prowadzenia nietypowej działalności gospodarczej non-profit. To, co w krótkim lub średnim okresie wydaje się jedynie działaniem zmierzającym do zmniejszenia problemu bezrobocia lub integracji wykluczonych w ramach przedsiębior- 
stwa społecznego działającego na potrzeby ekoturystyki, w długim okresie staje się elementem długookresowej strategii rozwoju lokalnego.

\section{Bibliografia}

Alter K.S., Przedsiębiorstwo spoteczne w szerszym kontekście, w: Wygnański J.J. (red.), Przedsiębiorstwo społeczne. Antologia kluczowych tekstów, FISE, Warszawa 2008.

Bohdziewicz-Lulewicz M., Sutuła J., Ekonomia spoleczna jako instrument rozwoju regionu oraz społeczności lokalnych, „Ekonomia Społeczna”. Wydanie specjalne, 2012, nr 2, s. 51-63.

Brelik A., Marketing terytorialny a kreowanie regionów, Zeszyty Naukowe SGGW, Polityki Europejskie, Finanse i Marketing 2010, nr 3(52), s. 322-328.

Cyło A., Zielony Rower - firma na turystycznym szlaku, „Biznes i Etos”, 2012, nr 3, s. 14-16, http://gospodarkapodkarpacka.pl/news/view/1796/zielony-rower-firmana-turystycznym-szlaku (20.11.2014).

Defourny J., Przedsiębiorstwo społeczne w poszerzonej Europie: koncepcja i rzeczywistość, w: „Ekonomia społeczna” II Europejska Konferencja Ekonomii Społecznej Kraków 2004, Związek Lustracyjny Spółdzielni Pracy, Ministerstwo Polityki Społecznej, Warszawa 2005.

Hausner J., Ekonomia społeczna jako kategoria rozwoju, w: J. Hausner (red.), Ekonomia społeczna a rozwój. Skrypt 1, MSAP UE w Krakowie, Kraków 2008, s. 11-25.

Hausner J., Laurisz N., Czynniki krytyczne tworzenia przedsiębiorstw społecznych. Przedsiębiorstwo spoleczne. Konceptualizacja, w: Hausner J. (red.), Przedsiębiorstwa społeczne w Polsce. Teoria i praktyka, MSAP UE w Krakowie, Kraków 2008.

Kazimierczak T., Zrozumieć ekonomię społeczna, w: T. Kazimierczak, M. Rymsza (red.), Kapitat spoteczny. Ekonomia spoleczna, Instytut Spraw Publicznych, Warszawa 2007.

Kazior B., Jarzębska A., Gałek O. (red.), Firma spoleczna w rozwoju lokalnym. Poradnik dla organizacji pozarzqdowych, Fundacja Partnerstwa dla Środowiska, Kraków 2008.

Kaźmierczak T., Przybysz I., Potkańska D., Przedsiębiorstwa społeczne: czynniki trwatości. Raport z I fazy monitoringu przedsiębiorstw społecznych, Warszawa 2011, http://centrumklucz.pl/cwps/wp-content/uploads/Przedsiebiorstwa_spoleczne_czynniki_trwalosci.pdf(12.11.2014).

Krajowy Program Rozwoju Ekonomii Społecznej, Ministerstwo Pracy i Polityki Społecznej, Warszawa 2014, Monitor Polski Dziennik 2014 r., poz. 811, t. 1.

Kwaśnicki W., Gospodarka spoteczna z perspektywy ekonomii liberalnej, „Trzeci Sektor" 2005, nr 2, s. 10-35.

Para A., Zasady zrównoważonego rozwoju turystyki - bariery i szanse dla branży turystycznej, Wyższa Szkoła Turystyki i Języków Obcych, Zeszyty Naukowe Turystyka i Rekreacja, 2013, 11(1), s. 5-15.

Pearse J., Social Enterprise in Anytown, Calouste Gulbenkian Foundation, London 2003.

Plan rozwoju lokalnego powiatu leskiego na lata 2004-2013, Starostwo Powiatowe w Lesku, Fundacja Wiedza i Rozwój, Nowy Sącz 2004, www.starostwolesko.home.pl/. /plan_rozwoju_lokalnego_powiatu_leski (18.11.2014).

Prądnicki C., Wykluczeni, „Biznes i Etos”, 2012, nr 3, s. 4-5. 
Pyzocha B., Przedsiębiorczość i podejmowane inicjatywy na szlaku Greenway „Zielony Rower”, wystapienie na Międzynarodowej Konferencji Greenways „Rozwój przedsiębiorczości na obszarach wiejskich w oparciu o zintegrowane produkty turystyczne - Szlaki Greenways", Lublin 20-23.10.2014, http://ksow.pl/fileadmin/user_upload/ksow.pl/PROJEKTY_ 2014/Szlaki_Greenways/Bogus\%C5\%82aw_Pyzocha_PL.pdf(20.12.2014).

Raftowicz-Filipkiewicz M., Marketing terytorialny jako narzędzie budowania przewagi konkurencyjnej gmin Doliny Baryczy, ,Nauki o Zarządzaniu” 2013, nr 1(3), s. 57-68.

Szpak J., Karpackie Centrum Turystyki Aktywnej „Zielony Rower” zaprasza, http://www.ekonomiaspoleczna.pl/wiadomosc/273757.html (15.10.2014).

Québec Declaration on Ecotourism, World Ecotourism Summit, Québec 19-22 May, 2002, $\mathrm{http} / / / \mathrm{www} . g d r c . o r g /$ uem/eco-tour/quebec-declaration.pdf(14.11.2014).

Zaręba D., Ekoturystyka, Wydawnictwo Naukowe PWN, Warszawa 2006.

Zaręba D., Ekoturystyka i odkrywanie dziedzictwa. Zbiór dobrych praktyk, Fundacja Fundusz Partnerstwa, Fundacja Partnerstwo dla Środowiska, Kraków 2008.

\section{Ecotourism as an area of activity of social economy entities Summary}

The article discusses the use of ecotourism in the activity of social economy entities. Ecotourism is a way of sustainable local development, the opportunity for revival and rebirth of the local communities, growth of citizens' entrepreneurship and reduction of the social and economic problems that precious natural and cultural areas of Poland face. Its purpose is to discuss such projects in Poland and to demonstrate that they can impact positively on the development of local communities. As an example of this kind of initiative is shown in detail the activity of the company called Zielony Rower Przedsiębiorstwo Społeczne created by Fundacja Bieszczadzka Partnerstwo dla Srodowiska. In article preparation were used various sources of literature, information collected on the website devoted to the social economy, documents and elaborations of the Foundation. The case study was the basic research method. 